\title{
Behavior Problems in Four-Year-Old Children from a Brazilian Birth Cohort
}

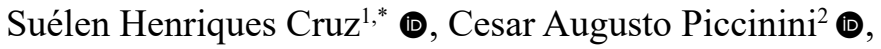 \\ Alicia Matijasevich ${ }^{3}$ (D) \& Iná Silva Santos ${ }^{1}$ (D) \\ ${ }^{1}$ Universidade Federal de Pelotas, Pelotas, RS, Brasil \\ ${ }^{2}$ Universidade Federal do Rio Grande do Sul, Porto Alegre, RS, Brasil \\ ${ }^{3}$ Universidade de São Paulo, São Paulo, SP, Brasil
}

\begin{abstract}
This study aimed to investigate the occurrence of behavior problems in 3750 four years old children from a birth cohort. Children were followed from birth to four years old through home visits, and questionnaires on child health and development and the Child Behavior Checklist 4-18/CBCL were applied. Prevalence rates were high (total problems $35.6 \%$ ), particularly externalizing problems, which occurred in $44.4 \%$ of children (48.3\% girls; $40.6 \%$ boys; $\mathrm{p}<0.001)$. Internalizing problems were less prevalent, occurring in $15.5 \%$ of children $(19.1 \%$ boys; $11.6 \%$ girls; $p<$ 0.001). Regardless of sex, there was a higher prevalence of behavioral problems in children with younger siblings, whose mothers had less education and had no partner.
\end{abstract}

KEYWORDS: behavior problems, internalizing, externalizing, preschoolers, birth cohort

\section{Problemas de Comportamento em Crianças Brasileiras de Quatro Anos de Idade}

\begin{abstract}
RESUMO - Este estudo objetivou investigar a ocorrência de problemas de comportamento em 3750 crianças pertencentes a uma coorte de nascimentos. As crianças foram acompanhadas do nascimento aos quatro anos de idade, por meio de visitas domiciliares, tendo sido aplicados instrumentos sobre saúde e desenvolvimento infantil e o Child Behavior Checklist 4-18/CBCL. As prevalências encontradas foram altas (total de problemas de comportamento: 35,6\%), com destaque para problemas de externalização, que ocorreram em 44,4\% das crianças (48,3\% meninas; $40,6 \%$ meninos; $\mathrm{p}<0,001)$. Problemas de internalização foram menos prevalentes, ocorrendo em $15,5 \%$ das crianças $(19,1 \%$ meninos; $11,6 \%$ meninas; $p<0,001)$. Independente do sexo, houve maior prevalência de problemas de comportamento em crianças com maior número de irmãos mais novos, cujas mães tinham menor escolaridade e não tinham companheiro.
\end{abstract}

PALAVRAS-CHAVE: problemas de comportamento, internalização, externalização, pré-escolares, estudo de coorte

Behavior problems in childhood are usually characterized by symptom patterns, defined by Achenbach (1991) as internalizing and externalizing. According to this author, children with internalization problems show an excessive control of emotions, thoughts, and behaviors, while children with externalization problems have difficulties in this control. Internalization problems comprise withdrawal, somatic complaints, sadness, fear, depression, and anxiety symptoms, while externalization problems include aggression, hyperactivity, disobedience, impulsivity, anger reactions and disruptive behaviors (Achenbach, 1991). Behavior problems can start in the preschool years (Davis et al., 2015; Olson et al., 2017) and can cause short and medium-term social, cognitive and emotional impairments, such as social difficulties (Hoglund \& Chisholm, 2014), low cognitive ability and poor academic functioning (Bub et

* E-mail: suhcruz.psi@outlook.com

- Submetido: 08/11/2016; Aceito: 14/08/2020. 
al., 2007), as well as lifelong anxiety, depression and other psychopathologies (Weeks et al., 2016).

Studies suggest that the occurrence of behavior problems is higher in children from families with lower socioeconomic status (Paterson et al., 2013; Gleason et al., 2011), whose mothers have fewer years of schooling (Velders et al., 2011; Liu et al., 2011) and are younger (LaGasse et al., 2012; Velders et al., 2011). In fact, low family socioeconomic level and parental education are generally associated with health problems in children (Currie \& Goodman, 2010), as it tends to expose them to social vulnerabilities such as living in neighborhoods with less security and access to assistance of any kind (Kim et al., 2019; Assis et al., 2009). The mother's age is considered an important predictor of emotional problems in the child, as it tends to influence the quality of mother-child affective interactions since birth. According to a literature review, teenage mothers tend to be less responsive to their children, providing a less supportive and stimulating family environment when compared to adult mothers (Levandowski et al., 2008).

Several family risk factors are associated with the occurrence of behavior problems in children. Maternal mental health problems, like depression and anxiety, are associated with an increased risk of children developing emotional and behavior problems (Goodman et al., 2011; Cooke et al., 2019). Although understanding the nature of the association between maternal-infant mental health problems is complex, because several mediating mechanisms are involved in this relationship, studies suggest that maternal depression can diminish the mother's parental capacity and negatively affect the quality of affective interactions with the child (Cooke et al., 2019; Cabrera et al., 2011; Ramchandani \& Psychogiou, 2009; Goodman, 2007). Furthermore, depressive mothers tend to show more hostile and less positive behaviors compared to non-depressed mothers (Lovejoy et al., 2000).

Another family risk factor associated with the occurrence of behavioral problems in children is the absence of a maternal partner at home (Durtschi et al., 2017; Choi \& Becher, 2019). Studies suggest that the involvement of a father figure is a protective factor for child development (Paterson et al., 2013; Cia \& Barham, 2009), for several reasons including co-parenting (Choi \& Becher, 2019; Jackson et al., 2013). From this perspective, mothers who do not have a partner may feel overloaded and stressed by parenting activities, which can influence their interactions with their children. For example, in a study of 492 dyads of single mothers of three-year-old children, it was found that the availability of social and instrumental support from partners was associated with better psychological and parental conditions, as well as fewer behavioral problems in their children (Jackson et al., 2013).

The presence of younger siblings was also identified as a risk factor for behavior problems (Volling et al., 2017), mainly due to the changes that the birth of a second child brings to the family. Mothers can become more impatient and restrictive, as they are focused on the care of a new baby, which can cause a decrease in maternal attention and in the quality of the interaction with the firstborn (Volling et al., 2017; de Oliveira \& Lopes, 2010). Thus, in some cases, the birth of a sibling can be considered an emotionally stressful event for the child, arousing reactions such as anxiety, feelings of abandonment and anger (Winnicott, 1966).

Regarding individual risk factors, studies have shown significant differences in the occurrence of behavior problems between boys and girls, however, there is no consensus in literature. Several studies indicate that the occurrence of behavior problems is higher among boys (Yamamoto \& Imai-Matsumura, 2019; LaGasse et al., 2012; Beyer et al., 2012; Velders, 2011; Fanti \& Henrich, 2010;), especially externalizing problems (Sauer et al., 2014; Henrichs et al., 2013; LaGasse et al., 2012; Gleason et al., 2011; Syed et al., 2007; Van Beijsterveldt et al., 2006; Stanger et al., 1997). However, some studies show a higher prevalence of behavior problems among girls, considered more vulnerable to internalization problems (CosentinoRocha \& Linhares, 2013; Chaplin et al., 2005; Olson \& Hoza, 1993). Psychological and cultural explanations regarding gender differences have been used to support these findings. For example, in many cultures, boys are considered more sociable and less able to control their aggression compared to girls, considered more tender and peaceful. (Yamamoto \& Matsumura, 2019; Else-Quest et al., 2006).

In addition to gender, other child individual factors typical of the perinatal period such as gestational age (prematurity), low birth weight, and postpartum complications have been associated with physical and mental health problems in children (Linsell et al., 2019; Velders et al., 2011). Although the neurobiological mechanisms involved in the association between perinatal factors and behavior problems are not sufficiently understood, it is believed that neurodevelopmental immaturity at birth and altered brain development superimposed on neonatal brain injuries may be the main contributors in the postnatal period, mediated by cognitive deficits and environmental influences (Linsell et al., 2019). Regarding environmental influences, factors such as parents' mental health, parenting styles or limited contact with family members and other children during long periods of hospitalization can prevent the development of coping strategies, emotional regulation and other skills in children born prematurely. (Wolke et al., 2014; Burnett, 2011). For example, parental care practices may be different when the child is premature or underweight, so that interaction with the baby in these cases may end up being impaired (Smith et al., 2006). In addition, studies on the mother-premature baby relationship indicate that mothers of premature babies are at high risk for mental problems, becoming more fragile for coping properly with the baby's birth and less adapted to their initial care (Kennell \& Klaus, 1998). 
Given the above, the aim of this study was to investigate the occurrence of behavioral problems in four-year-old children, as well as their association with sociodemographic, family, and individual risk factors. This work is expected to fill an existing gap, which is the lack of population-based studies that assess the prevalence of these problems in young children. In addition, it is expected that the results can support effective intervention strategies in childhood mental health, as it is an ideal time for the prevention of various future diseases.

\section{METHODS}

\section{Participants}

The study included 3,799 children ( $51.9 \%$ boys) aged four years $(M=49.5$ months, $S D=1.7$ months $)$ and their mothers, selected from a longitudinal study entitled "2004 Pelotas Birth Cohort". The methodology of this study was described elsewhere (Santos et al., 2011). In 2004, all children born in the urban area of Pelotas/Brazil were identified and their mothers were invited to participate. Of all 4,263 live births, only $0.8 \%$ of mothers refused to participate in the perinatal study. The interviews were conducted when the children were 3,12 and 24 months and four years old, with follow-up rates of $95.7 \%, 94.3 \%, 93.5 \%$ and $92.0 \%$, respectively.

\section{Study Design and Procedures}

This is an epidemiological study, with a longitudinal design, in which the participants were prospectively followed from birth (in 2004) to four years of age (in 2008). During this period, several visits were made to the families and structured questionnaires were applied to the mothers, with questions about children's health and development, in addition to sociodemographic and family information.

Children's behavior problems, the outcome of the present study, were assessed at the age of four, using the Child Behavior Checklist 4-18 - CBCL (Achenbach, 1991), a structured questionnaire containing 118 items with behavioral descriptions referring to a list of psychopathological symptoms, divided into eight scales: I) withdrawn; II) somatic complaints; III) anxiety/depression; IV) problems with social contact; V) thinking problems; VI) attention problems; VII) breaking rules/disruptive behavior; and VIII) aggressive behavior. CBCL is usually a self-administered instrument, however, due to the variation in the educational level of the children's mothers, it was read by the interviewers and the mothers made their choices for each item, classifying whether the described behavior was absent $($ score $=0)$; sometimes present $($ score $=1)$; or frequently present $($ score $=2)$. The total score of behavior problems was obtained from the sum of the raw scores obtained on all scales. Internalization problems score was obtained by the sum of scales I, II and III, while externalization problems score was obtained by the sum of the points of the scales VII and VIII. The CBCL was adapted and validated in Brazil (Bordin et al., 1995).

Child individual risk factors (gestational age, birth weight and perinatal problems) were collected at birth, while sociodemographic and family variables were obtained at the age of four. The Edinburgh Postnatal Depression Scale - EPDS (Cox et al., 1996) was used to assess maternal depression, using a score of 11 or more points as the cutoff point for moderate and severe depressive symptoms, as suggested by Santos et al. (2007). Child's life events assessed emotionally important situations for the child occurring in the month prior to the interview, such as separation from parents, changes in life, and loss of loved ones.

This study was approved by the Research Ethics Committee of the Federal University of Pelotas. All participants received full explanations about the study and signed an Informed Consent Form, which guaranteed data confidentiality and the right to interrupt their participation at any time, without prejudice to themselves.

\section{Analysis}

In order to assess behavior problems, the raw scores of the CBCL were transformed into standardized scores according to the normative sample (T-score). After that, children were classified as non-clinical ( $\mathrm{T}$ scores $<67$ ), borderline $(\mathrm{T} \geq 67$ and $\leq 70)$ and clinical $(\mathrm{T}>70)$, for each CBCL / 4-18 scale. For internalization and externalization scales, children were classified as non-clinical $(T<60)$, borderline $(T \geq 60$ and $\leq 63)$ and clinical $(T>63)$. Borderline children were included in the clinical category, as suggested by Achenbach in research situations (1991).

Behavior problems prevalence's (total, internalization, and externalization) were calculated according to each of the exposure variables using the chi-square test for heterogeneity. The analysis was performed by gender stratification, as, according to the literature, the occurrence of behavior problems can be different between boys and girls and, therefore, this variable can be a confounder. Differences were considered statistically significant when a p-value lower than 0.05 was obtained. The statistical program STATA version 14.0 was used to perform the analysis (StataCorp, 2015). 


\section{RESULTS}

The description of the cohort participants is presented in Table 1. Regarding individual child factors, about $15 \%$ of children were born preterm, $10 \%$ were underweight, and $12.6 \%$ had some perinatal complication. Concerning family variables, $19.5 \%$ of the children had at least one younger sibling, $79.8 \%$ of the mothers had a partner living in the same house and $25.1 \%$ of them had depressive symptoms. At four years old, $13.5 \%$ of the children had some life event capable of causing behavioral changes (for example, separation from parents, change of residence or school, illness, or death of someone close to them). Most mothers had 11 or more years of schooling and almost $49.4 \%$ were between 20 and 29 years old at the time of their children's birth. There was no significant difference between boys and girls in any of the exposure variables described above. The final sample included 3,750 children for whom complete information about behavior problems was available.

Figure 1 shows the occurrence of behavior problems in the whole cohort and according to gender. The overall prevalence of behavioral problems was $35.6 \%$, being higher in girls than in boys $(37.3 \%$ and $33.6 \%$, respectively; $p=$ 0.009 ). Externalizing problems were the most prevalent, occurring in $44.4 \%$ of children, with higher prevalence in girls $(48.3 \%$ versus $40.6 \%$; $p<0.001)$. Internalization problems were less prevalent $(15.5 \%)$ and their occurrence was higher in boys $(19.1 \%$ versus $11.6 \%$; $p<0.001)$. The most prevalent CBCL subscales were rule breaking/ disruptive behavior (20.5\%) and aggressive behavior $(20.6 \%)$, with higher occurrence among girls. On the rule-breaking/disruptive behavior scale, the prevalence in girls was $23.9 \%$, while in boys it was $17.4 \%(p<0.001)$. On the aggressive behavior scale, the prevalence in girls was $23.8 \%$, while in boys it was $17.6 \%(p<0.001)$. The withdrawn subscale had a prevalence of $5.1 \%$, and its occurrence in boys was twice that of girls $(6.8$ and $3.3 \%$ respectively; $p<0.001$ ). On the somatic complaints scale, whose prevalence was $3.2 \%$, the occurrence was also higher among boys ( $4.3 \%$ and $2.2 \% ; p<0.001)$. Anxiety-depression symptoms occurred in $2.3 \%$ of children and there was no gender difference. The prevalence of attention problems was $2.8 \%$, occurring more in girls than in boys $(3.7 \%$ and $2.1 \%$; $p=0.003$ ). The prevalence of thinking problems was $5.2 \%$ and social contact problems was $3.1 \%$, with no differences between boys and girls.

Tables 2 and 3 show the prevalence of behavioral problems according to sociodemographic, family and child's individual risk factors, stratified by gender. Among boys (Table 2), there was an association between behavior problems and maternal education, with a higher prevalence of behavior problems in boys whose mothers had fewer years of schooling, and a tendency for problems to decrease with increasing education. Boys whose mothers had 0 to 3 years of schooling had higher occurrence of behavior problems than boys whose mothers had 11 or more years of schooling (49.7\% and $24.9 \% ; p<0.001)$. Following this pattern, maternal education was significantly associated with problems of internalization and externalization (Table 2).

The absence of a maternal partner and the number of younger siblings were significantly associated with behavior problems. Boys whose mothers did not have a partner had a higher prevalence of behavior problems than those whose mothers had a partner $(40.2 \%$ and $32.0 \% ; p<0.002)$, as well as a higher prevalence of externalizing problems $(49.7 \%$ and $38.4 \% ; p<0.001)$. Furthermore, boys who had two or more siblings had more behavior problems than those without siblings $(55.3 \%$ and $31.2 \% ; p<0.001)$, and the same was true for externalizing and internalizing problems.

Table 3 presents the prevalence of behavior problems among girls. As with boys, total behavior problems, as well as internalizing and externalizing problems, are significantly associated with maternal education. The fewer years of schooling, the greater the prevalence of behavior problems. Absence of a maternal partner and number of siblings was also associated with the occurrence of behavior problems. Girls whose mothers had no partner showed higher prevalence of total behavior problems $(50.0 \%$ versus $34.6 \%$; $p<0.001)$, as well as externalization $(60.1 \%$ versus $45.4 \% ; p$ $<0.001)$ and internalization problems ( $14.8 \%$ versus $10.8 \%$; $p<0.034$ ), compared with girls whose mothers had a partner. Likewise, girls who had two or more siblings showed more total behavior problems than those who had no siblings $(57.1 \%$ versus $35.1 \% ; p<0.001)$ and this relationship was also found for internalization problems $(25.7 \%$ versus $9.7 \%$; $p<0.001)$ and externalization problems $(65.7 \%$ versus $46.2 \% ; p<0.001)$.

Differently from the results found for boys, for girls, both gestational age and birth weight were associated with behavioral problems. Girls who were born in less than 37 weeks' gestation had a higher prevalence of total and internalizing problems compared to girls who were born after more than 37 weeks' gestation (total behavior problems $43.0 \%$ versus $36.3 \%$; $p=0.045$; internalization problems $16.1 \%$ versus $10.8 \% ; p=0.016$ ). Birth weight was also associated with a higher occurrence of total behavioral problems, with girls born with low weight having a higher prevalence than those born with normal weight $(45.1 \%$ versus $36.4 \%$; $p=0.021$ ). 
Table 1

Sample Characteristics

\begin{tabular}{|c|c|c|c|}
\hline \multirow{2}{*}{ Variables } & Total & Boys & Girls \\
\hline & $\%(N)$ & $\%(N)$ & $\%(N)$ \\
\hline \multicolumn{4}{|c|}{ Sociodemographic } \\
\hline \multicolumn{4}{|c|}{ Income $(N=3799)$} \\
\hline Q1 & $20.1(765)$ & $20.7(359)$ & $19.8(317)$ \\
\hline Q2 & $21.2(804)$ & $20.7(359)$ & $21.9(350)$ \\
\hline Q3 & $18.8(713)$ & $19.7(340)$ & 18.7 (299) \\
\hline Q4 & $19.9(758)$ & $19.9(344)$ & $19.1(305)$ \\
\hline Q5 & $20.0(759)$ & $19.0(329)$ & $20.5(327)$ \\
\hline \multicolumn{4}{|c|}{ Maternal schooling $(N=3783)$} \\
\hline $0-3$ & $7.8(293)$ & $7.4(145)$ & $8.1(148)$ \\
\hline $4-7$ & $31.9(1207)$ & $31.6(621)$ & $32.2(586)$ \\
\hline $8-10$ & $22.3(845)$ & $21.4(419)$ & $23.4(426)$ \\
\hline $11+$ & $38.0(1438)$ & $39.6(777)$ & $36.3(661)$ \\
\hline \multicolumn{4}{|c|}{ Maternal age $(N=3670)$} \\
\hline$<20$ & $18.8(689)$ & $18.4(348)$ & $19.2(341)$ \\
\hline $20-29$ & $49.5(1818)$ & $50.4(953)$ & $48.6(865)$ \\
\hline $30-39$ & $28.3(1038)$ & $27.9(528)$ & $28.7(510)$ \\
\hline $40+$ & $3.4(125)$ & $3.3(63)$ & $3.5(62)$ \\
\hline \multicolumn{4}{|l|}{ Familial } \\
\hline \multicolumn{4}{|c|}{ Depressive symptoms $(N=3748)$} \\
\hline No & $74.9(2808)$ & $75.0(1454)$ & $74.9(1348)$ \\
\hline Yes & $25.1(940)$ & $25.0(484)$ & $25.1(452)$ \\
\hline \multicolumn{4}{|c|}{ Maternal partner $(N=3790)$} \\
\hline No & $20.3(768)$ & $20.2(398)$ & $20.3(370)$ \\
\hline Yes & $79.7(3022)$ & $79.8(1569)$ & $79.7(1453)$ \\
\hline \multicolumn{4}{|c|}{ Younger siblings $(N=3799)$} \\
\hline 0 & $78.6(2986)$ & $78.5(1550)$ & $78.6(1436)$ \\
\hline 1 & $19.5(739)$ & $19.5(384)$ & $19.4(355)$ \\
\hline $2+$ & $1.9(74)$ & $2.0(39)$ & $2.0(35)$ \\
\hline \multicolumn{4}{|c|}{ Child's life events ( $N=3798$ ) } \\
\hline No & $86.5(3287)$ & $86.9(1691)$ & $86.2(1557)$ \\
\hline Yes & $13.5(511)$ & $13.1(254)$ & $13.8(250)$ \\
\hline \multicolumn{4}{|l|}{ Individual } \\
\hline \multicolumn{4}{|c|}{ Gestational age $(N=4168)$} \\
\hline$<37$ weeks & $15.1(629)$ & $13.4(358)$ & $14.1(252)$ \\
\hline$\geq 37$ weeks & $84.9(3539)$ & $86.6(1670)$ & $85.9(1532)$ \\
\hline \multicolumn{4}{|c|}{ Birth weight ( $N=4186$ ) } \\
\hline$<2,500 \mathrm{~g}$ & $10.1(459)$ & $7.9(152)$ & $10.4(185)$ \\
\hline$\geq 2,500 \mathrm{~g}$ & $89.9(3727)$ & $92.1(1778)$ & $89.6(1601)$ \\
\hline \multicolumn{4}{|c|}{ Perinatal problems $(N=4216)$} \\
\hline Não & $87.4(3685)$ & $87.4(1693)$ & $87.6(1573)$ \\
\hline Sim & $12.6(531)$ & $12.6(245)$ & $12.4(223)$ \\
\hline
\end{tabular}




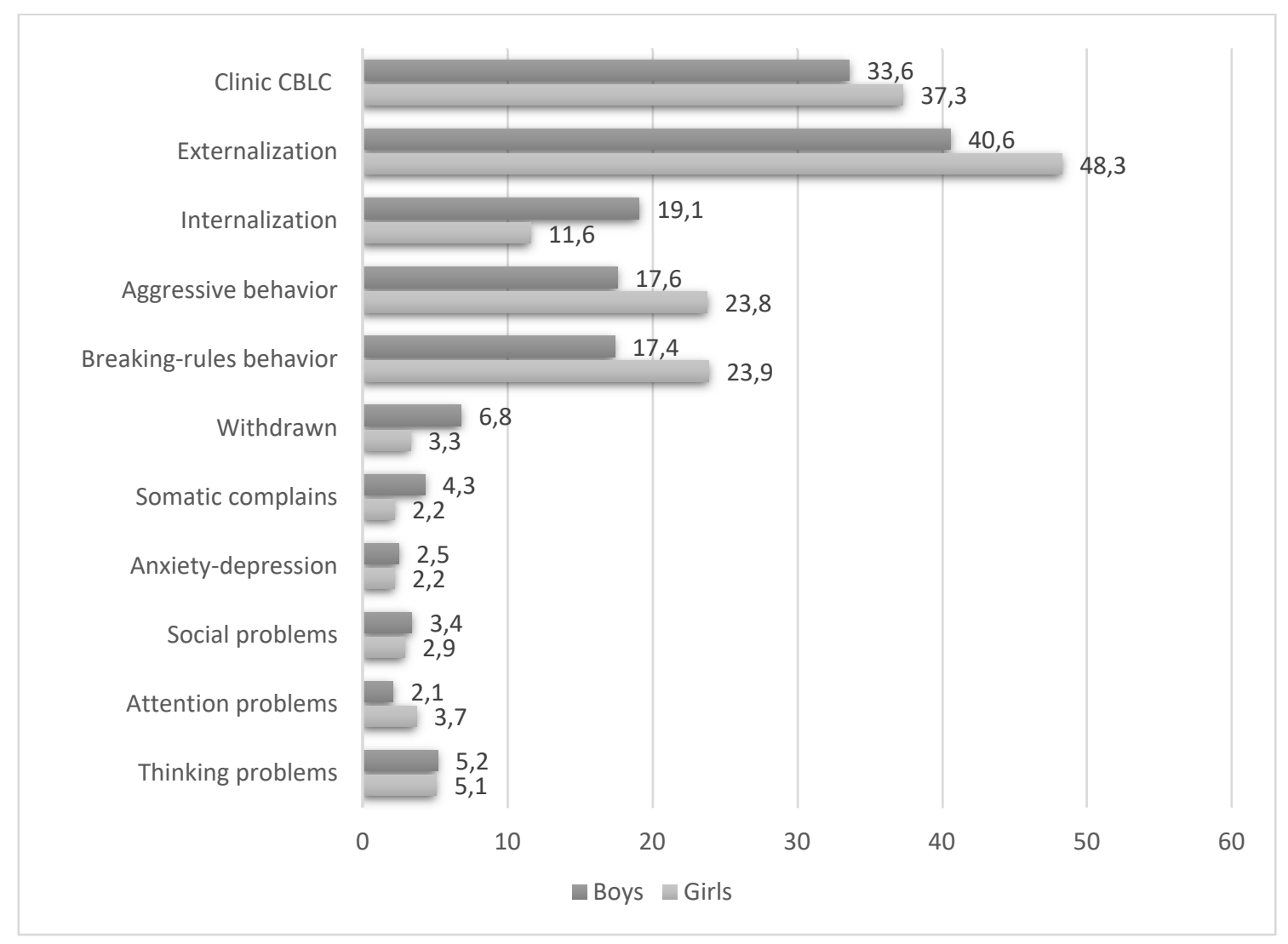

Figure 1. Behavior Problems, by Gender $(\mathrm{N}=3750)$

Table 2

Prevalence of Behavioral Problems According to Sociodemographic, Familial, and Individual Factors in Boys ( $n=1944)$

\begin{tabular}{|c|c|c|c|c|c|c|}
\hline \multirow{2}{*}{ Variables } & \multicolumn{2}{|c|}{ Total behavior problems } & \multicolumn{2}{|c|}{ Internalization } & \multicolumn{2}{|c|}{ Externalization } \\
\hline & $\%(n)$ & $p$ & $\%(n)$ & $p$ & $\%(n)$ & $P$ \\
\hline \multicolumn{7}{|l|}{ Sociodemographic } \\
\hline Income & & 0.405 & & 0.578 & & 0.323 \\
\hline Q1 & $35.1(124)$ & & $19.8(70)$ & & $41.9(148)$ & \\
\hline Q2 & $31.8(113)$ & & $16.1(57)$ & & $44.2(157)$ & \\
\hline Q3 & $34.6(115)$ & & $19.9(66)$ & & $38.0(126)$ & \\
\hline Q4 & $30.3(103)$ & & $18.8(64)$ & & $37.7(128)$ & \\
\hline Q5 & $36.6(119)$ & & $20.6(67)$ & & $42.2(137)$ & \\
\hline Maternal schooling & & $<0.001$ & & $<0.001$ & & $<0.001$ \\
\hline $0-3$ & $49.7(71)$ & & $29.4(42)$ & & $51.1(73)$ & \\
\hline $4-7$ & $43.3(266)$ & & $27.7(170)$ & & $50.2(308)$ & \\
\hline $8-10$ & $30.3(125)$ & & $17.2(71)$ & & 41.7 (172) & \\
\hline $11+$ & $24.9(190)$ & & $11.4(87)$ & & $30.7(234)$ & \\
\hline Maternal age & & 0.215 & & 0.221 & & 0.217 \\
\hline$<20$ & $29.1(101)$ & & $15.9(55)$ & & $36.6(127)$ & \\
\hline $20-29$ & $34.3(327)$ & & $19.9(190)$ & & $41.6(396)$ & \\
\hline $30-39$ & $35.7(188)$ & & $19.2(101)$ & & $42.7(225)$ & \\
\hline $40+$ & $31.8(20)$ & & $25.4(16)$ & & $34.9(22)$ & \\
\hline
\end{tabular}


Table 2

Cont.

\begin{tabular}{|c|c|c|c|c|c|c|}
\hline \multirow{2}{*}{ Variables } & \multicolumn{2}{|c|}{ Total behavior problems } & \multicolumn{2}{|c|}{ Internalization } & \multicolumn{2}{|c|}{ Externalization } \\
\hline & $\%(n)$ & $p$ & $\%(n)$ & $p$ & $\%(n)$ & $P$ \\
\hline \multicolumn{7}{|l|}{ Familial } \\
\hline Depressive symptoms & & 0.239 & & 0.480 & & 0.511 \\
\hline No & $32.8(477)$ & & $18.8(273)$ & & $41.0(595)$ & \\
\hline Yes & $35.7(173)$ & & $20.3(98)$ & & $39.3(190)$ & \\
\hline Maternal partner & & 0.002 & & 0.329 & & $<0.001$ \\
\hline No & $40.2(156)$ & & $20.9(81)$ & & $49.7(193)$ & \\
\hline Yes & $32.0(496)$ & & $18.7(290)$ & & $38.4(595)$ & \\
\hline Younger siblings & & $<0.001$ & & $<0.001$ & & 0.002 \\
\hline 0 & $31.2(477)$ & & $16.3(249)$ & & $38.6(591)$ & \\
\hline 1 & $41.2(155)$ & & $27.7(104)$ & & $47.6(179)$ & \\
\hline $2+$ & $55.3(21)$ & & $50.0(19)$ & & $52.6(20)$ & \\
\hline Child's life events & & 0.204 & & 0.460 & & 0.059 \\
\hline No & $34.1(576)$ & & $19.4(327)$ & & $41.4(700)$ & \\
\hline Yes & $30.0(76)$ & & $17.4(44)$ & & $35.2(89)$ & \\
\hline \multicolumn{7}{|l|}{ Individual } \\
\hline Gestational age & & 0.547 & & 0.406 & & 0.939 \\
\hline$<37$ & $35.3(89)$ & & $21.0(53)$ & & $40.9(103)$ & \\
\hline$\geq 37$ & $33.4(550)$ & & $18.8(310)$ & & $40.6(669)$ & \\
\hline Birth weight & & 0.269 & & 0.651 & & 0.583 \\
\hline$<2500 \mathrm{~g}$ & $29.6(45)$ & & $17.8(27)$ & & $42.8(65)$ & \\
\hline$\geq 2500 \mathrm{~g}$ & $34.0(595)$ & & $19.3(337)$ & & $40.5(708)$ & \\
\hline Perinatal problems & & 0.370 & & 0.942 & & 0.865 \\
\hline No & $33.8(564)$ & & $19.0(317)$ & & $40.6(678)$ & \\
\hline Yes & $30.8(74)$ & & $19.2(46)$ & & $40.0(96)$ & \\
\hline
\end{tabular}

Note. ${ }^{*}$ Chi-square test for heterogeneity

Table 3

Prevalence of Behavioral Problems According to Sociodemographic, Familial, and Individual Factors in Firls ( $n=1806$ )

\begin{tabular}{|c|c|c|c|c|c|c|}
\hline \multirow{2}{*}{ Variables } & \multicolumn{2}{|c|}{ Total behavior problems } & \multicolumn{2}{|c|}{ Internalization } & \multicolumn{2}{|c|}{ Externalization } \\
\hline & $\%(n)$ & $p$ & $\%(n)$ & $p$ & $\%(n)$ & $p$ \\
\hline \multicolumn{7}{|l|}{ Sociodemographic } \\
\hline Income & & 0.090 & & 0.061 & & 0.331 \\
\hline Q1 & $40.4(127)$ & & $13.1(41)$ & & $48.7(153)$ & \\
\hline Q2 & $33.2(115)$ & & $8.1(28)$ & & $48.8(169)$ & \\
\hline Q3 & $42.5(127)$ & & $15.0(45)$ & & $50.8(152)$ & \\
\hline Q4 & $35.6(108)$ & & $10.6(32)$ & & $51.5(156)$ & \\
\hline Q5 & $35.4(114)$ & & $10.6(34)$ & & $43.8(141)$ & \\
\hline Maternal schooling & & $<0.001$ & & $<0.001$ & & $<0,001$ \\
\hline $0-3$ & $55.6(80)$ & & $20.1(29)$ & & $60.4(87)$ & \\
\hline $4-7$ & $46.8(272)$ & & $16.5(96)$ & & $57.5(334)$ & \\
\hline $8-10$ & $33.0(139)$ & & $8.3(35)$ & & $44.4(187)$ & \\
\hline $11+$ & $28.6(187)$ & & $7.5(49)$ & & $40.2(263)$ & \\
\hline Maternal age & & 0.585 & & 0.693 & & 0.974 \\
\hline$<20$ & $39.7(135)$ & & $11.2(38)$ & & $48.2(164)$ & \\
\hline $20-29$ & $37.7(326)$ & & $12.5(108)$ & & $49.0(424)$ & \\
\hline $30-39$ & $37.3(190)$ & & $10.6(54)$ & & $48.0(245)$ & \\
\hline $40+$ & 30.7 (19) & & $9.7(6)$ & & $46.8(24)$ & \\
\hline
\end{tabular}




\begin{tabular}{|c|c|c|c|c|c|c|}
\hline \multirow{2}{*}{ Variables } & \multicolumn{2}{|c|}{ Total behavior problems } & \multicolumn{2}{|c|}{ Internalization } & \multicolumn{2}{|c|}{ Externalization } \\
\hline & $\%(n)$ & $p$ & $\%(n)$ & $p$ & $\%(n)$ & $p$ \\
\hline \multicolumn{7}{|l|}{ Familial } \\
\hline Depressive symptoms & & 0.888 & & 0.801 & & 0.647 \\
\hline No & $37.8(509)$ & & $11.7(158)$ & & $48.6(655)$ & \\
\hline Yes & $37.4(169)$ & & $11.3(51)$ & & $47.3(214)$ & \\
\hline Maternal partner & & $<0.001$ & & 0.034 & & $<0.001$ \\
\hline No & $50.0(183)$ & & $14.8(54)$ & & $60.1(220)$ & \\
\hline Yes & $34.6(497)$ & & $10.8(155)$ & & $45.4(653)$ & \\
\hline Younger siblings & & $<0.001$ & & $<0.001$ & & 0.001 \\
\hline 0 & $35.1(498)$ & & $9.7(138)$ & & $46.2(657)$ & \\
\hline 1 & $46.6(163)$ & & $18.0(63)$ & & $55.1(193)$ & \\
\hline $2+$ & $57.1(20)$ & & $25.7(9)$ & & $65.7(23)$ & \\
\hline Child's life events & & 0.750 & & 0.988 & & 0.983 \\
\hline No & $37.9(589)$ & & $11.6(181)$ & & $48.3(752)$ & \\
\hline Yes & $36.8(92)$ & & $11.6(29)$ & & $48.4(121)$ & \\
\hline \multicolumn{7}{|l|}{ Individual } \\
\hline Gestational age & & 0.045 & & 0.016 & & 0.070 \\
\hline$<37$ & $43.0(107)$ & & $16.1(40)$ & & $53.4(133)$ & \\
\hline$\geq 37$ & $36.3(551)$ & & $10.8(164)$ & & $47.2(716)$ & \\
\hline Birth weight & & 0.021 & & 0.162 & & 0.104 \\
\hline$<2500 \mathrm{~g}$ & $45.1(83)$ & & $14.7(27)$ & & $53.8(99)$ & \\
\hline$\geq 2500 \mathrm{~g}$ & $36.4(576)$ & & $11.3(177)$ & & $47.5(751)$ & \\
\hline Perinatal problems & & 0.897 & & 0.379 & & 0.574 \\
\hline No & $48.2(750)$ & & $37.4(582)$ & & $11.4(178)$ & \\
\hline Yes & $48.6(107)$ & & $40.5(89)$ & & $12.7(28)$ & \\
\hline
\end{tabular}

Note. * Chi-square test for heterogeneity

\section{DISCUSSION}

The prevalence of behavior problems found in this study was high (35.6\%) and this finding is relevant considering the size of the sample $(n=3750)$ and the age of the children. Another study with a smaller sample, carried out in Brazil (Borsa et al., 2011) also found a high prevalence of behavior problems $(39.3 \%)$, but in children aged between 8 and 12 years. A similar occurrence of behavior problems in schoolchildren $(34.0 \%)$ was found in a study from another developing country, Pakistan (Syed et al., 2007). In addition to this high overall prevalence of behavior problems, the high occurrence of externalizing (44.4\%) and internalizing $(15.5 \%)$ problems is impressive, indicating that a significant number of young children have behavioral and/or emotional difficulties, suffering of symptoms of hyperactivity, anxiety, and depression.

Although some studies indicate that externalization problems are the most prevalent in children (Anselmi et al., 2010; Anselmi et al., 2004), others indicate a higher prevalence of internalization problems (Borsa et al., 2011; Furniss et al., 2006). Therefore, there is no consensus in literature. Regarding the high prevalence of externalization problems found in children from this study, literature suggests that it tends to decrease with age (Davis et al., 2015; Olson et al., 2017; Keiley et al., 2000) and a possible explanation for the high occurrence of these problems at four years of age is the fact that, at this stage, it is common for children to present behaviors interpreted by adults as negative, such as disobedience, tantrums and aggression. (Yamamoto \& Imai-Matsumura, 2019). At least in part, these behaviors can be considered typical of that period of development, when children are growing up and becoming more autonomous, asserting themselves to the world (Bee, 1997) sometimes using physical aggression to deal with conflicting situations (Tremblay et al., 2004). It must be difficult for parents to discriminate between behaviors that are an adaptive expression of the child's autonomy, from symptoms that could be classified as psychopathological. This may be overestimating the prevalence of externalizing problems. In addition, children with externalizing problems tend to have more problems related to behavior to express 
their psychological anxieties and conflicts (Borsa et al., 2011; Campbell, 2006), which can be enhanced by this phase of development of autonomy, and this fact can justify the higher prevalence of externalization problems than internalization, which in this age group would tend to be underestimated (Cabaj et al., 2014).

Among the investigated behavior problems, regardless of gender, the prevalence of aggressive behavior $(20.6 \%)$ and rule breaking/disruptive behavior (20.5\%) is significantly higher than other problems such as withdrawal, somatic complaints and anxiety-depression, problems with social contact, attention and thinking. This high occurrence of aggressive and rule-breaking/disruptive behavior corroborates the fact that, at age four, these behaviors are quite common, as children are already beginning to develop more adaptive ways of dealing with conflicts, but still use aggressive behaviors in these situations. (Girard et al., 2019; Tremblay et al., 2004).

Regarding the sociodemographic risk factors investigated, corroborating the findings of other studies (Velders et al., 2011; Liu et al., 2011), there was a higher prevalence of behavior problems among children whose mothers had fewer years of schooling. These findings highlight the importance of social determinants for child health (Currie \& Goodman, 2020; Kim et al., 2019; Assis et al., 2009), especially the negative influence of low maternal education on child development. According to Currie and Goodman (2020), maternal education is strongly correlated with high rates of neonatal mortality and child health in general, mainly due to the choices that mothers with less education make, which impact on their relationship with their children and on their habits. developed in the family environment. From a psychological point of view, maternal education can influence the quality of interaction established with the child through different means, but mainly in parenting styles. In the case of low education, parenting styles can be more punitive, which can be a risk factor for several psychological problems in childhood and later in life (Carr \& Pike, 2012).

Among the family risk factors studied, both the absence of a maternal partner and the greater number of siblings were associated with a higher occurrence of behavioral problems in children, regardless of gender. The absence of a maternal partner showed an association with the overall occurrence of behavior problems and externalization problems. This finding agrees with other studies, which suggests that mothers who do not receive emotional and economic support tend to overburden themselves with their children's education and emotional support functions, which in turn can induce the occurrence of behavior problems in their children (Volling et al., 2017; Jackson et al., 2013), especially externalization problems (Florsheim et al., 1998). The number of siblings was also shown to be an important risk factor for behavioral problems in children. According to Volling et al. (2017), the birth of a second child can increase pre-existing problems in the family structure, in addition to causing psychological problems in older children (Volling et al., 2017). Kowaleski-Jones and Dunifon (2004) point out the birth of a sibling as a common event for many preschool-age children, being one of the most stressful in early childhood. Younger children tend to react more negatively to the birth of a sibling than older children, who already have the ability of understanding and tolerance in the face of family changes at this time of transition, since they have better developed social and cognitive skills (Kowaleski- Jones \& Dunifon 2004; Kramer \& Ramsburg, 2002). In this sense, it can be thought that the changes that occur in the family environment with the birth of a second child, especially the reduced attention of the mother and the positive interactions with the firstborn (de Oliveira \& Lopes, 2010), can directly affect child's emotional development, thus, causing more behaviors considered by parents to be problematic.

Regarding individual prenatal factors, such as gestational age and low birth weight and their relationship with behavioral problems, an association was found only with internalization problems in girls. Girls born with a lower gestational age and birth weight had more internalization problems than those born with a gestational age and adequate weight. One explanation for this may be the fact that children with preterm birth and low birth weight tend to have deficits in their neuropsychological development, which can lead to psychological problems (Linsell et al., 2019; Velders et al., 2011), including behavioral problems, throughout life (Aarnoudse-Moens et al., 2009). In a meta-analysis study relating preterm birth and low birth weight, a strong and positive association was also found between these factors and internalization problems, as well as problems with attention and school performance (Aarnoudse-Moens et al., 2009).

About gender differences in the occurrence of behavioral problems, there is no consensus in literature to support these findings. Although several studies show that boys have more externalization problems (Sauer et al., 2014; Henrichs et al., 2013; LaGasse et al., 2012; Gleason et al., 2011; Syed et al., 2007; Van Beijsterveldt et al., 2006; Stanger et al., 1997) and girls have more internalization problems (Cosentino-Rocha \& Linhares, 2013; Olson \& Hoza, 1993) others found no differences (Borsa et al., 2011; Coyne \& Thompson, 2011; Utendale \& Hastings, 2011; Anselmi et al., 2004). These controversial findings may be due to different factors, both methodological (instruments used to assess behavioral problems) and sociocultural (different parental conceptions of behavioral problems) and may also change over the years. For example, age and gender differences may play an important role in the findings, especially regarding aggression, which may be associated with hormonal differences (Van Beijsterveldt et al., 2006) and other developmental processes specific to girls and boys, such as reactivity to stressful events, which may occur differently between the two groups (Marturano et al., 2005). 
However, it is necessary to consider sociocultural issues present in early childhood education, based on gender differences (Santos, 2017; Vianna \& Finco, 2009; Faria, 2006). For example, boys and girls learn differently how to control feelings, and develop cognitive skills and role models to meet the expectations society and culture have about male and female roles. Thus, while parents can be more attentive to controlling aggression in girls, with boys they can focus on the importance of blocking expressions of feelings such as tenderness, sensitivity, and affection. Therefore, in some cultures, boys tend to be more active, independent, and aggressive, characteristics that are evident from the first years of life, when they prefer games that involve physical contact and fights, while girls tend to be calmer and to present better social interactions (Ribeiro, 2006; Carvalho et al., 1993).

The findings bring these issues to the discussion, since, contrary to what was expected, girls had more externalizing problems and boys had more internalizing problems. Given that the behaviors presented by children are linked to social and cultural expectations, a possible explanation is that the changes related to male and female gender roles, which have occurred over the years in society, (Beltrame \& Bottoli, 2010; Negreiros \& Féres-Carneiro, 2004) are reverberating in the children's universe. For example, changes that have taken place in the contemporary family, such as greater participation of women in the labor market, as well as more effective contribution of men in household chores and in child rearing, may be directly influencing the behavior of boys and girls. With this, it is possible that the girls are, at least in part, reflecting a little of the behavior of women, who seek to gain greater participation and impose themselves in a traditionally male world. On the other hand, boys may be experimenting with new ways to express their feelings, not only through aggressive and disruptive behaviors, but also allowing themselves to show more emotions such as sadness and anxiety - mirroring and reflecting the presence of parents or other sensitive male role models.

This study has a few limitations. First, information about children's behavior problems was obtained only based on mothers' reports that, despite being considered valid informants about their children's health (Nauta et al, 2004), they may not be sensitive enough to detect behavior problems, underestimating the prevalence of certain problems in children, since they are emotionally involved with them. Or, on the contrary, the mothers may overestimate the occurrence of behavioral problems in their children, if they have, for example, psychopathology such as depression (Ringoot et al., 2015). Therefore, the ideal would be to perform a triangulation of the data (Stake, 2005), through other informants or procedures that could identify child's behavior problems (i.e., father, teacher, observation), since there is a possibility that the report of mothers reflects their mental state and/or even the mother-child relationship in addition to the symptoms inherent to the child (Ringoot et al., 2015). Because the identification of behavior problems in children also depends on the role that adults play in their lives, many problems may not be detected even by parents, suggesting that the occurrence of behavior problems can be underestimated, particularly those of internalization (Cabaj et al., 2014; Achenbach et al., 1987), which are often more difficult to notice. Besides, due to the variation in the educational level of the mothers in the present study, which could cause difficulties in reading and/or understanding the instrument, the CBCL was read by the interviewers and each item was answered by the mothers. Thus, the results may be underestimated to some extent, if some mothers felt constrained to report their children's behavior problems to interviewers.

Furthermore, when interpreting the results, it should be considered that children's behavior problems were accessed through a screening instrument. Given the large number of subjects, this questionnaire offers useful information, but has little specificity in diagnostics, which may be offered by psychiatric interviews. And, no doubt, it is necessary to move towards a methodological and conceptual sophistication in the identification of behavior problems, in view of the complexity of this phenomenon, whose conceptual and operational definition is closely related to family, social and cultural issues. Despite these limitations, the present study reveals several important results, which contribute to understanding the phenomenon of behavior problems in young children, as well as supporting the planning of public policies. We are facing a high incidence of behavioral problems, which has been revealed by several studies, whether in the country or abroad. In developing countries such as Brazil, these findings are of greater importance, as they seem to be associated with situations of social vulnerability of families (e.g., low maternal education), factors that enhance the emergence of behavior problems and prevent public actions aimed at minimizing its effects on child development. Therefore, it is necessary to intensify efforts in risk prevention and in promoting factors that reduce the incidence of behavior problems in young children. Otherwise, there is a possibility of chronicity and development of more serious behavior problems in adolescence and adulthood. It is important to consider not only the future consequences of behavior problems, but the current psychological suffering that affects everyone involved, whether the child, parents, other family members and society. 


\section{REFERENCES}

Aarnoudse-Moens, C. S. H., Weisglas-Kuperus, N., van Goudoever, J. B., \& Oosterlaan, J. (2009). Meta-analysis of neurobehavioral outcomes in very preterm and/or very low birth weight children. Pediatrics, 124(2), 717-728. https://doi.org/10.1542/ peds.2008-2816

Achenbach, T. M. (1991). Manual for the Child Behavior Checklist 14-18 and profile. Burlington.

Achenbach, T.M., McConaughy, S.H., Howell, C.T. (1987). Child/adolescent behavioral and emotional problems: Implications of cross informant correlations for situational specificity. Psychological bulletin, 101, 213-32. https://doi. org/10.1037/0033-2909.101.2.213

Anselmi, L., Fleitlich-Bilyk, B., Menezes, A. M. B., Araújo, C. L., \& Rohde, L. A. (2010). Prevalence of psychiatric disorders in a Brazilian birth cohort of 11-year-olds. Social Psychiatry and Psychiatric Epidemiology, 45(1), 135-142. https://doi. org/10.1007/s00127-009-0052-2

Anselmi, L., Piccinini, C. A., Barros, F. C., \& Lopes, R. S. (2004). Psychosocial determinants of behaviour problems in Brazilian preschool children. Journal of Child Psychology and Psychiatry, 45(4), 779-788. https://doi.org/10.1111/j.14697610.2004.00271.x

Assis, S. G., Avanci, J. Q., \& Oliveira, R. D. V. C. D. (2009). Socioeconomic inequalities and child mental health. Revista de Saúde Pública, 43, 92-100. https://www.scielosp.org/article/ rsp/2009.v43suppl1/92-100/en/

Bee, H. (1997). O ciclo vital. Artes Médicas.

Beltrame, G. R., \& Bottoli, C. (2010). Retratos do envolvimento paterno na atualidade. Barbarói, 32, 205-226. http://dx.doi. org/10.17058/barbaroi.v0i0.1380

Beyer, T., Postert, C., Müller, J. M., \& Furniss, T. (2012). Prognosis and continuity of child mental health problems from preschool to primary school: Results of a four-year longitudinal study. Child Psychiatry \& Human Development, 43(4), 533543. https://doi.org/10.1007/s10578-012-0282-5

Bordin, I. A., Mari, J. J., \& Caeiro, M. F. (1995). Validação da versão brasileira do Child Behavior Checklist (CBCL). Revista ABP-APAL, 17(2), 55-66.

Borsa, J. C., Souza, D. S. D., \& Bandeira, D. R. (2011). Prevalência dos problemas de comportamento em uma amostra de crianças do Rio Grande do Sul. Psicologia: Teoria e Prática, 13(2), 15-29. https://www.redalyc.org/articulo.oa?id=115022577004

Bub, K. L., McCartney, K., Willett, J. B., (2007). Behavior problem trajectories and firstgrade cognitive ability and achievement skills: A latent growth curve analysis. Journal of Educational Psychology, 99(3), 653-670. https://doi.org/10.1037/00220663.99.3.653.

Burnett, A. C. (2011). Prevalence of psychiatric diagnoses in preterm and full-term children, adolescents and young adults: A metaanalysis. Psychological Medicine 41, 2463-2474. https://doi. org/10.1017/S003329171100081X

Cabaj, J. L., McDonald, S. W., \& Tough, S. C. (2014). Early childhood risk and resilience factors for behavioural and emotional problems in middle childhood. BMC Pediatrics, 14(1), 166177. https://doi.org/10.1186/1471-2431-14-166

Cabrera, N. J., Fagan, J., Wight, V., \& Schadler, C. (2011). Influence of mother, father, and child risk on parenting and children's cognitive and social behaviors. Child Development, 82(6), 1985-2005. https://doi.org/10.1111/j.1467-8624.2011.01667.x

Campbell, S. B. (2006). Behavior problems in preschool children: Clinical and developmental issues. Guilford Press.

Carr, A., \& Pike, A. (2012). Maternal scaffolding behavior: Links with parenting style and maternal education. Developmental Psychology, 48(2), 543-551. https://doi.org/10.1037/a0025888
Carvalho, A., Beraldo, K., Santos, F., \& Ortega, R. (1993). Brincadeiras de menino, brincadeiras de menina. Psicologia: Ciência e Profissão, 13(1-4), 30-33. https://doi.org/10.1590/ S1414-98931993000100006

Chaplin, T. M., Cole, P. M., \& Zahn-Waxler, C. (2005). Parental socialization of emotion expression: Gender differences and relations to child adjustment. Emotion, 5(1), 80-88. https:// psycnet.apa.org/buy/2005-02259-007

Choi, J. K., \& Becher, E. H. (2019). Supportive coparenting, parenting stress, harsh parenting, and child behavior problems in nonmarital families. Family Process, 58(2), 404-417. https:// doi.org/10.1111/famp.12373

Cia, F., \& Barham, E. J. (2009). O envolvimento paterno e o desenvolvimento social de crianças iniciando as atividades escolares. Psicologia em Estudo, 14(1), 67-74.

Cooke, J. E., Racine, N., Plamondon, A., Tough, S., \& Madigan, S. (2019). Maternal adverse childhood experiences, attachment style, and mental health: Pathways of transmission to child behavior problems. Child Abuse \& Neglect, 93, 27-37. https:// doi.org/10.1016/j.chiabu.2019.04.011

Cosentino-Rocha, L. \& Linhares, M. B. M. (2013). Temperamento de crianças e diferenças de gênero. Paidéia, 23(54), 63-72. https://doi.org/10.1590/1982-43272354201308

Cox, J. L., Chapman, G., Murray, D., \& Jones, P. (1996). Validation of the Edinburgh Postnatal Depression Scale (EPDS) in nonpostnatal women. Journal of Affective Disorders, 39(3), 185189. https://doi.org/10.1016/0165-0327(96)00008-0

Coyne, L. W., \& Thompson, A. D. (2011). Maternal depression, locus of control, and emotion regulatory strategy as predictors of preschoolers' internalizing problems. Journal of Child and Family Studies, 20(6), 873-883. https://doi.org/10.1007/ s10826-011-9455-2

Currie, J., \& Goodman, J. (2020). Parental socioeconomic status, child health, and human capital. The Economics of Education, (18), 239-248. https://doi.org/10.1016/B978-0-12-8153918.00018-5

de Oliveira, D. S., \& Lopes, R. D. C. S. (2010). Implicações emocionais da chegada de um irmão para o primogênito: Uma revisão da literatura. Psicologia em Estudo, 15(1), 97-106.

Davis, S., Votruba-Drzal, E., Silk, J. S. (2015). Trajectories of internalizing symptoms from early childhood to adolescence: Associations with temperament and parenting. Social Development, 24(3), 501-520. https://doi.org/10.1111/ sode. 12105

Durtschi, J. A., Soloski, K. L., \& Kimmes, J. (2017). The dyadic effects of supportive coparenting and parental stress on relationship quality across the transition to parenthood. Journal of Marital and Family Therapy, 43(2), 308-321. https://doi. org/10.1111/jmft.12194

Else-Quest, N. M., Hyde, J. S., Goldsmith, H. H., \& Van Hulle, C. A. (2006). Gender differences in temperament: A metaanalysis. Psychological Bulletin, 132(1), 33-72. https://doi. org/10.1037/0033-2909.132.1.33

Fanti, K. A., \& Henrich, C. C. (2010). Trajectories of pure and co-occurring internalizing and externalizing problems from age 2 to age 12: Findings from the National Institute of Child Health and Human Development Study of Early Child Care. Developmental Psychology, 46(5), 1159-1175. https:// doi.org/10.1037/a0020659

Faria, A. L. G. (2006). Pequena infância, educação e gênero: Subsídios para um estado da arte. Cadernos Pagu, 26, 279-287.

Florsheim, P., Tolan, P., \& Gorman-Smith, D. (1998). Family relationships, parenting practices, the availability of male family members, and the behavior of inner-city boys in single- 
mother and two-parent families. Child Development. 69,143747. https://doi.org/10.1111/j.1467-8624.1998.tb06222.x

Furniss, T., Beyer, T., \& Guggenmos, J. (2006). Prevalence of behavioural and emotional problems among six-yearsold preschool children. Social Psychiatry and Psychiatric Epidemiology, 41(5), 394-399. https://doi.org/10.1007/s00127006-0045-3

Girard, L. C., Tremblay, R. E., Nagin, D., \& Côté, S. M. (2019). Development of aggression subtypes from childhood to adolescence: A group-based multi-trajectory modelling perspective. Journal of Abnormal Child Psychology, 47(5), 825-838. https://doi.org/10.1007/s10802-018-0488-5

Gleason, M., Zamfirescu, A., Egger, H., Nelson, A., Fox, N., \& Zeanah, C. (2011). Epidemiology of psychiatric disorders in very young children in a Romanian pediatric setting. European Child Adolescent Psychiatry, 20, 527-535. https:// doi.org/10.1007/s00787-011-0214-0

Goodman, S. H. (2007). Depression in mothers. Annual Review of Clinic Psychology, 3, 107-135. https://doi.org/10.1146/ annurev.clinpsy.3.022806.091401

Goodman, S. H., Rouse, M. H., Connell, A. M., Broth, M. R., Hall, C. M., \& Heyward, D. (2011). Maternal depression and child psychopathology: A meta-analytic review. Clinical Child and Family Psychology Review, 14(1), 1-27. https://doi. org/10.1007/s10567-010-0080-1

Henrichs, J., Rescorla, L., Donkersloot, C., Schenk, J. , Raat, H., Jaddoe, V., ..., Tiemeier, H. (2013). Early vocabulary delay and behavioral/emotional problems in early childhood: The generation R study. Journal of Speech, Language, and Hearing Research, 56, 553-566. https://doi.org/10.1044/10924388(2012/11-0169)

Hoglund, W.G., \& Chisholm, C. A. (2014). Reciprocating risks of peer problems and aggression for children's internalizing problems. Developmental Psychology, 50(2), 586-599. https:// doi.org/10.1037/a0033617.

Jackson, A. P., Preston, K. S., \& Thomas, C. A. (2013). Single mothers, nonresident fathers, and preschoolers' socioemotional development: Social support, psychological well-being, and parenting quality. Journal of Social Service Research, 39(1), 129-140. https://doi.org/10.1080/01488376.2012.723241

Keiley, M. K., Bates, J. E., Dodge, K. A., \& Pettit, G. S. (2000). A cross-domain growth analysis: Externalizing and internalizing behaviors during 8 years of childhood. Journal of Abnormal Child Psychology, 28(2), 161-179. https://doi. org/10.1023/A:1005122814723

Kennell, J. H., \& Klaus, M. H. (1998). Bonding: Recent observations that alter perinatal care. Pediatrics in Review, 19, 4-12. https:// doi.org/10.1023/A:1005122814723

Kim, Y., Lee, S., Jung, H., Jaime, J., \& Cubbin, C. (2019). Is neighborhood poverty harmful to every child? Neighborhood poverty, family poverty, and behavioral problems among young children. Journal of Community Psychology, 47(3), 594-610. https://doi.org/10.1002/jcop.22140

Kowaleski-Jones, L., \& Dunifon, R. (2004). Children's home environments understanding the role of family structure changes. Journal of Family Issues, 25(1), 3-28. https://doi. org/10.1177/0192513X03256516

Kramer, L., \& Ramsburg, D. (2002). Advice given to parents on welcoming a second child: A critical review. Family Relations, 51(1), 2-14. https://doi.org/10.1111/j.17413729.2002.00002.x

LaGasse, L. L., Derauf, C., Smith, L. M., Newman, E., Shah, R., Neal, C, ..., \& Lester, M. (2012). Prenatal methamphetamine exposure and childhood behavior problems at 3 and 5 years of age. Pediatrics, 129, 681-688. https://doi.org/10.1542/ peds.2011-2209

Levandowski, D. C., Piccinini, C. A., \& Lopes, R. D. C. S. (2008). Maternidade Adolescente. Estudos de Psicologia
(Campinas), 25(2), 251-263. https://doi.org/10.1590/S0103166X2008000200010

Linsell, L., Johnson, S., Wolke, D., Morris, J., Kurinczuk, J. J., \& Marlow, N. (2019). Trajectories of behavior, attention, social and emotional problems from childhood to early adulthood following extremely preterm birth: A prospective cohort study. European Child \& Adolescent Psychiatry, 28(4), 531542. https://doi.org/10.1007/s00787-018-1219-8

Liu, J., Cheng, H., \& Leung, P. W. (2011). The application of the Preschool Child Behavior Checklist and the Caregiver-Teacher Report form to Mainland Chinese children: Syndrome structure, gender differences, country effects, and inter-informant agreement. Journal of Abnormal Child Psychology, 39(2), 251-264. https://doi.org/10.1007/s10802-010-9452-8

Lovejoy, M. C., Graczyk, P. A., O'Hare, E., \& Neuman, G. (2000). Maternal depression and parenting behavior: A meta-analytic review. Clinical Psychology Review, 20(5), 561-592. https:// doi.org/10.1016/S0272-7358(98)00100-7

Marturano, E. M., Toller, G. P., \& Elias, L. C. D. S. (2005). Gênero, adversidade e problemas socioemocionais associados à queixa escolar. Estudos de Psicologia (Campinas), 22(4), 371-380. https://doi.org/10.1590/S0103-166X2005000400005

Nauta, M. H., Scholing, A., Rapee, R. M., Abbott, M., Spence, S. H., \& Waters, A. (2004). A parent-report measure of children's anxiety: Psychometric properties and comparison with childreport in a clinic and normal sample. Behaviour Research and Therapy, 42(7), 813-839. https://doi.org/10.1016/S00057967(03)00200-6

Negreiros, T. C. D. G. M., \& Féres-Carneiro, T. (2004). Masculino e feminino na família contemporânea. Estudos e Pesquisas em Psicologia, 4(1), 34-47. http://pepsic.bvsalud.org/scielo. php?script $=$ sci_arttext\&pid $=$ S1808-42812004000100004\&ln $\mathrm{g}=$ pt\&tlng=pt.

Olson, S. L., Choe, D. E., \& Sameroff, A. J. (2017). Trajectories of child externalizing problems between ages 3 and 10 years: Contributions of children's early effortful control, theory of mind, and parenting experiences. Development Psychopathology, 29(4), 1333-1351. https://doi:10.1017/ S095457941700030X.

Olson, S. L., \& Hoza, B. (1993). Preschool development antecedents of conduct problems in children beginning school. Journal of Clinical Child Psychology, 22(1), 60-67. https://doi. org/10.1207/s15374424jccp2201_6

Paterson, J., Taylor, S., Schluter, P., \& Iusitini, L. (2013). Pacific Islands Families (PIF) study: Behavioural problems during childhood. Journal of Child and Family Studies, 22(2), 231243. https://doi.org/10.1007/s10826-012-9572-6

Ramchandani, P., \& Psychogiou, L. (2009). Paternal psychiatric disorders and children's psychosocial development. The Lancet, 374(9690), 646-653. https://doi.org/10.1016/S01406736(09)60238-5

Ribeiro, J. S. B. (2006). Brincadeiras de meninas e de meninos: Socialização, sexualidade e gênero entre crianças. Cadernos Pagu, 26, 145-168. https://doi.org/10.1590/S010483332006000100007

Ringoot, A. P., Tiemeier, H., Jaddoe, V. W., So, P., Hofman, A., Verhulst, F. C., \& Jansen, P. W. (2015). Parental depression and child well-being: Young children's self-reports helped addressing biases in parent reports. Journal of Clinical Epidemiology, 68(8), 928-938. https://doi.org/10.1016/j. jclinepi.2015.03.009

Santos, S. V. S. (2017). Socialização de gênero na educação infantil: Continuidades e rupturas vivenciadas pelas crianças na família, na igreja e na escola. Educação (UFSM), 42(3), 731-750. https://doi.org/10.5902/1984644428325

Santos, I. S., Barros, A. J., Matijasevich, A., Domingues, M. R., Barros, F. C., \& Victora, C. G. (2011). Cohort profile: The 2004 Pelotas (Brazil) birth cohort study. International Journal 
of Epidemiology, 40(6), 1461-1468. https://doi.org/10.1093/ ije/dyq130

Santos, I. S., Matijasevich, A., Tavares, B. F., Barros, A. J., Botelho, I. P., Lapolli, C., ..., \& Barros, F. C. (2007). Validation of the Edinburgh Postnatal Depression Scale (EPDS) in a sample of mothers from the 2004 Pelotas Birth Cohort Study. Cadernos de Saúde Pública, 23(11), 2577-2588. https://doi.org/10.1590/ S0102-311X2007001100005

Sauer, K., Barkmann, C., Klasen, F., Bullinger, M., Glaeske, G., \& Ravens-Sieberer, U. (2014). How often do German children and adolescents show signs of common mental health problems? Results from different methodological approaches-a crosssectional study. BMC Public Health, 14(1), 229-42. https:// doi.org/10.1186/1471-2458-14-229

Schroeder, A., Slopen, N., \& Mittal, M. (2018). Accumulation, timing, and duration of early childhood adversity and behavior problems at age 9. Journal of Clinical Child \& Adolescent Psychology, 49(1), 36-49. https://doi.org/10.1080/15374416 .2018 .1496440

Landry, S. H., Smith, K. E., \& Swank, P. R. (2006). Responsive parenting: establishing early foundations for social, communication, and independent problem-solving skills. Developmental psychology, 42(4), 627. https://doi. org/10.1037/0012-1649.42.4.627

Stake, R. E. (2005). Qualitative case studies. Em N. K. Denzin \& Lincoln, Y. S. (Eds.). The Sage handbook of qualitative research (3rd ed., pp. 443-466). Sage Publications Ltd.

Stanger, C., Achenbach, T. M., \& Verhulst, F. C. (1997). Accelerated longitudinal comparisons of aggressive versus delinquent syndromes. Development and Psychopathology, 9(1), 43-58. https://doi.org/10.1017/S0954579497001053

StataCorp. (2015). Stata Statistical Software: Release 14 [Software de Computador]. StataCorp LP.

Syed, E. U., Hussein, S. A., \& Mahmud, S. (2007). Screening for emotional and behavioural problems amongst 5-11-yearold school children in Karachi, Pakistan. Social Psychiatry and Psychiatric Epidemiology, 42(5), 421-427. https://doi. org/10.1007/s00127-007-0188-x

Tremblay, R. E., Nagin, D. S., Seguin, J. R., Zoccolillo, M., Zelazo, P. D., Boivin, M., ... \& Japel, C. (2004). Physical aggression during early childhood: Trajectories and predictors. Pediatrics, 114(1), e43-e50. https://doi.org/10.1542/ peds.114.1.e43
Utendale, W. T., \& Hastings, P. D. (2011). Developmental changes in the relations between inhibitory control and externalizing problems during early childhood. Infant and Child Development, 20(2), 181-193. https://doi.org/10.1002/ icd.691

Van Beijsterveldt, C. E. M., Hudziak, J. J., \& Boomsma, D. I. (2006). Genetic and environmental influences on cross-gender behavior and relation to behavior problems: A study of Dutch twins at ages 7 and 10 years. Archives of Sexual Behavior, 35(6), 647658. https://doi.org/10.1007/s10508-006-9072-0

Velders, F., Dieleman, G., Henrichs, J., Jaddoe, V., Hofman, A., Verhulst, F., ..., Tiemeier, H. (2011). Prenatal and postnatal psychological symptoms of parents and family functioning: The impact on child emotional and behavioral problems. European Child and Adolescent Psychiatry, 20, 341-350. https://doi.org/10.1007/s00787-011-0178-0

Vianna, C., \& Finco, D. (2009). Meninas e meninos na Educação Infantil: Uma questão de gênero e poder. Cadernos pagu, 33, 265-283. https://doi.org/10.1590/S0104-83332009000200010

Volling, B. L., Gonzalez, R., Oh, W., Song, J. H., Yu, T., Rosenberg, L., ... \& Stevenson, M. M. (2017). Developmental trajectories of children's adjustment across the transition to siblinghood: Pre-birth predictors and sibling outcomes at one year. Wiley. https://www-personal.umich.edu

Weeks, M., Ploubidis, G. B., Cairney, J., Wild, T. C., Naicker, K., \& Colman, I. (2016). Developmental pathways linking childhood and adolescent internalizing, externalizing, academic competence, and adolescent depression. Journal of Adolescence, 51, 30-40. https://doi.org/10.1016/j. adolescence.2016.05.009.

Winnicott, D. W. (1966). A criança e o seu mundo (A. Cabral, Trad.). Zahar.

Wolke, D., Eryigit Madzwamuse, S., Gutbrod, T. (2014). Very preterm/very low birthweight infants' attachment: Infant and maternal characteristics. Archives of Disease in Childhood: Fetal and Neonatal Edition, 99, 70-75.

Yamamoto, N., \& Imai-Matsumura, K. (2019). Gender differences in executive function and behavioural self-regulation in 5 years old kindergarteners from East Japan. Early Child Development and Care, 189(1), 56-67. https://doi.org/10.1080/03004430.2 017.1299148 